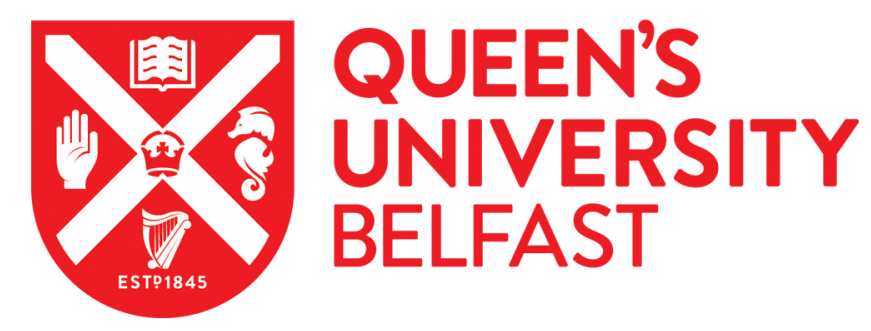

\title{
Victim Personal Statements in Managing Victims' Voices in Sentencing in Northern Ireland: Taking a more Procedural Justice Approach
}

Moffett, L. (2017). Victim Personal Statements in Managing Victims' Voices in Sentencing in Northern Ireland: Taking a more Procedural Justice Approach. Northern Ireland Legal Quarterly, 68(4).

https://nilq.qub.ac.uk/index.php/nilq/article/view/64

Published in:

Northern Ireland Legal Quarterly

Document Version:

Peer reviewed version

Queen's University Belfast - Research Portal:

Link to publication record in Queen's University Belfast Research Portal

Publisher rights

Copyright 2017 QUB School of Law.This work is made available online in accordance with the publisher's policies. Please refer to any applicable terms of use of the publisher.

\section{General rights}

Copyright for the publications made accessible via the Queen's University Belfast Research Portal is retained by the author(s) and / or other copyright owners and it is a condition of accessing these publications that users recognise and abide by the legal requirements associated with these rights.

Take down policy

The Research Portal is Queen's institutional repository that provides access to Queen's research output. Every effort has been made to ensure that content in the Research Portal does not infringe any person's rights, or applicable UK laws. If you discover content in the Research Portal that you believe breaches copyright or violates any law, please contact openaccess@qub.ac.uk. 


\title{
Victim Personal Statements in Managing Victims' Voices in Sentencing in Northern Ireland: Taking a more Procedural Justice Approach $^{1}$
}

\author{
by Luke Moffett* \\ '[Y]ou could actually have a good decent case and your victim could just ruin it for you.'2
}

Victims bring a certain amount of chaos to trials, despite calls for greater sensitivity to their needs in criminal proceedings over the past few decades. Many governments have included victims in criminal trials through Victim Personal Statements (VPS) to improve the legitimacy and self-sufficiency of their criminal justice systems. ${ }^{3}$ While Ashworth ${ }^{4}$ and Sanders ${ }^{5}$ argue that VPS make little difference to sentencing decisions, Roberts and Erez assert that such statements are not redundant, but can improve victim satisfaction and help judges to contextualise the crime. ${ }^{6}$ In light of these debates this article examines the use of VPS in sentencing in Northern Ireland through the lens of procedural justice. Early social psychologist theorists on procedural justice found that participations' perceptions of fairness and respect were dependent on how they were allowed to express their interests or 'voice' and how this shaped outcomes determined by third-party decision makers. ${ }^{7}$ Such research has informed victimology and more recently criminal justice policy of increasing victim satisfaction through procedural fairness, but with less emphasis on victims' input in informing outcomes.

This article explores the extent to which VPS deliver procedural justice, as not only being sensitive to victims' input, but also how their statements can help to inform and shape sentencing decisions. This article grounds its analysis on research conducted in Northern Ireland. Victim Personal Statements in Northern Ireland are noteworthy as they development by judges in the 1980s to better respond to victims' harm in sentencing. In the past few years there have been an increasing move towards a policy-orientated improvement of victim satisfaction, which has seen the statements widened to all crimes. This article begins by

\footnotetext{
* Senior lecturer, School of Law, Queen’s University Belfast. Email: 1.moffett@qub.ac.uk

${ }^{1}$ This work was kindly supported through the Socio-Legal Studies Association small grants awards.

${ }^{2}$ Prosecutor A, Interview 3, June 2015

${ }^{3}$ R. Elias, The Politics of Victimization: Victims, Victimology and Human Rights (Oxford University Press 1986), 231.

${ }^{4}$ A. Ashworth, Victim Impact Statements and Sentencing, Criminal Law Review (1993), 498-509.

${ }^{5}$ A. Sanders, Victim impact statements: don't work, can't work, Criminal Law Review (2001), 447-458.

${ }^{6} \mathrm{~J}$. Roberts, and E. Erez, Communication in Sentencing: Exploring The Expressive Function of Victim Impact Statements, International Review of Victimology 10 (2004), 223-244.

${ }^{7}$ John Thibaut and Laurens Walker, A Theory of Procedure, California Law Review 66 (1977) 541566.
} 
outlining theoretical debates on the use of victim statements in sentencing, focusing its analysis through the lens of procedural justice. The following section traces the emergence of VPS in common law criminal proceedings, in particular the case study of Northern Ireland. The following section outlines the process of giving a VPS, how this can be framed by criminal justice actors, and the difficulties of a victim making a statement. The subsequent section concentrates on the impact of the VPS on sentencing decisions, taking into consideration the role of the victim from perspectives of defence counsel, judges and prosecutors, and intermediaries. In concluding the article finds that while victims are able to voice their harm, the extent to which it is heard and impacts on sentencing is very much dependent on the judge and the articulation of the statement. As such procedural justice may be more about improving respect for victims in decision making in how the VPS is used in sentencing, rather than increasing their procedural 'rights'. ${ }^{8}$ In closing the piece considers new ways forward in improving victim satisfaction of VPS in NI and engendering procedural justice.

\section{Methodology}

This article is based on research conducted in Northern Ireland (NI) during June-October 2015 involving semi-structured interviews with 24 professionals including judges (4), defence counsel (3), representatives from the Public Prosecution Service (5), Department of Justice representatives (4), Family Liaison Officers in the PSNI (Police Service of Northern Ireland) (5), and (3) members of Victim Support NI and National Society for the Prevention of Cruelty to Children (NSPCC). Respondents were a mixture of male and female (50:50). Purposive sampling was used to identify key actors based on their experience and role through gatekeepers in these organisations and snowballing. Interviews lasted between 25 and 70 minutes, were audio-recorded and then transcribed. Data was collected, coded and analysed using key themes identified during project with NVivo. The identities of respondents were anonymised and are referred to based on their profession. Judges included senior justices in the NI Court of Appeal, criminal and magistrates courts to reflect the widening of victim statements from murder, rape and GBH to all crimes, including those coming before magistrate courts. Questions focused on the impact of the reform, the process of giving a VPS, perceptions of procedural justice for victims and their engagement with criminal justice actors, and whether VPS had impact on sentencing. While this project examines the procedural justice aspects of victims' statements in sentencing, victims were not interviewed, given the breadth of crimes the VPS covers and the focus of the research being on how VPS impacts on the criminal justice system and actors within it, rather than victims' perceptions.

\footnotetext{
${ }^{8}$ Ashworth, n.4, 509.
} 
Some anonymised examples of VPS were provided to the author. This research also analysed media coverage of cases and examined sentencing judgments and remarks. This involved looking through reported and unreported judgments on LexisNexus and the NI Courts and Tribunals Service case database sentencing judgments and relevant appeals for when and how victim impact statements and victim personal statements were used or reported in decisions.

\section{Victim Personal Statements as Procedural Justice}

Social psychologists have long had an interest in procedural justice of participants and the role of third parties with regards to their perceptions of fairness in decision-making and arbitration processes. Early research on procedural justice by Thibaut and Walker found that participants who were able to exercise their voice in procedures which affected them and influenced decision-making had improved satisfaction than those who were unable to express their views. ${ }^{9}$ Thibaut and Walker split procedural justice into process-control, capacity to present evidence, and decision-control, authority over the final decision. ${ }^{10}$ Tyler clarifies these down to consistency, representation and accuracy; consistency is based on comparison to prior decision, representation on the extent to which participants can make their case, and accuracy in how decisions are reached taking into account participants' input. ${ }^{11}$ With regards to representation, while it is subjective to the values and beliefs of the individual, ${ }^{12}$ exercising voice can have instrumental or value-expressive effects. ${ }^{13}$ With the instrumental perspective the participant recognises that their input does not determine the third-party's decision, but are able to state their case and support the objectiveness and legitimacy of the third-party arbiter in reaching a decision. Value-expressive effects are where the participant's input has no effect on the outcome but participants appreciate being given the opportunity to voice their concerns.

Tyler suggests that value in voicing concerns is only shared by participants where a decision maker considers their views, and this can be emphasised by decision makers in how they communicate and explain their decisions. ${ }^{14}$ If decision makers do not consider participants' interests and communicating to them in the long term it can lead to frustration and lack of engagement, undermining improving participants' self-esteem or personal worth

\footnotetext{
${ }^{9}$ Thibaut and Walker, n.6.

${ }^{10}$ Leventhal suggests six criteria: consistency, the ability to suppress bias, decision quality, correctability, representation and ethicality. See Gerald Leventhal, What should be done with equity theory? in K. Gergen, M. Greenberg, and R. Weiss (eds.) Social Exchange: Advances in Theory and Research, Plenum (1980) 27-55.

${ }^{11}$ Tom R. Tyler, What is procedural justice? Criteria used by citizens to assess the fairness of legal procedures, Law and Society Review 22(1) (1988) 103-135, 107.

${ }^{12}$ Leventhal, n.9.

${ }^{13}$ Tom R. Tyler, Conditions Leading to Value-Expressive Effects in Judgments of Procedural Justice:

A Test of Four Models, Journal of Personality and Social Psychology, 52(2) (1987) 333-344, 333.

${ }^{14}$ Ibid, 342.
} 
through the process. ${ }^{15}$ This group value approach goes beyond the participant's perceptions of being treated fairly, to include how such input by participants is considered in decision making processes as respected members of the community, thereby adding value by exhibiting social inclusion. ${ }^{16}$

Victimologists have used procedural justice as a lens to examine how victims' satisfaction can be improved in criminal justice processes. Wemmers suggests that victim satisfaction and perceptions of fairness are shaped by how they are treated by criminal justice actors, including feelings of respect, how their input is valued, and perceptions of objectivity of decision makers. ${ }^{17}$ Research by Lind and others suggest that procedural justice can be significant to victims despite a negative outcome in criminal proceedings, such as a lower sentence or acquittal. ${ }^{18}$ By allowing victims to voice their views and concerns through participation, such as making a statement for sentencing, it can help to affirm their dignity and self-worth. ${ }^{19}$ For victims personal statements in sentencing allows them to have a voice or input into the criminal justice system, which is supposed to provide them with important procedural justice benefits of inclusion and respect. ${ }^{20}$ Indeed, hearing victims' voices can acknowledge the importance of their agency and worth in shaping appropriate proceedings and outcomes.

A more critical approach to procedural justice is that while being sensitive to victims, VPS may be just a way to allow victims to voice their views in the criminal justice system and mollify them with procedural fairness without considering their interests in sentencing. This can reflect a dissonance between procedural and substantive justice in that victimsensitive processes have no impact on outcomes of proceedings. Procedural justice factors of sentencing consistency and decision accuracy may be in conflict when allowing victims to present evidence on the nature of their personal harm, and thus consistency with other sentencing decision can be less important for individual victims in their perceptions of procedural justice. ${ }^{21}$ However, the quality of decision-making in outcomes, such as sentencing, can be important to victims in terms of their perceptions of fairness, based on the

\footnotetext{
15 Ibid. 343.

${ }^{16}$ Mary Margaret Giannini, Measured Mercy: Managing the Intersection of Executive Pardon Power and Victims' Rights with Procedural Justice Principles, Ohio State Journal of Criminal Law 13(1) 2015-2016 89-137 123-124; Jan-Willem van Prooijen and Johan C. Karremans, Procedural Justice and the Hedonic Principle: How Approach Versus Avoidance Motivation Influences the Psychology of Voice, Journal of Personality and Social Psychology, 91(4) (2006), 686 - 697

${ }^{17}$ J. Wemmers, Victims in the Criminal Justice System (Kugler 1996)

${ }^{18}$ E. Lind., L. Walker, S. Kurtz, L. Musante, J. W. Thibaut, Procedure and Outcome Effects on Reactions to Adjudicated Resolution of Conflicts of Interests, Journal of Personality and Social Psychology 39 (1980) 643-653.

${ }^{19}$ T. R. Tyler, Procedural Justice, Legitimacy, and the Effective Rule of Law, Crime and Justice 30 (2003), 283-357, 350.

${ }^{20}$ E. Erez, Who's afraid of the big bad victim? Victim impact statements as victim empowerment and enhancement of justice, Criminal Law Review (1999) 545-556, 555.

${ }^{21}$ Tyler n.13, 107
} 
ethicality and neutrality of judges. ${ }^{22}$ In relation to this study, perceptions of third party decision-makers (judges and prosecutors) and facilitators (intermediaries), but not victims, were sought to determine to what extent victims' exercise of voice was considered in sentencing judgments (i.e. outcomes). This is analysed against current policy and legal reforms and theoretical procedural justice considerations of instrumental and/or valueexpressive uses of victim participation.

Any sort of intrusion by victims in the criminal trial has to be carefully managed, even if the responsibility of the defendant has been settled at trial. This is to ensure fair proceedings and that the sentence is a factual and evidential decision-making process based on the crime of which defendant is convicted. ${ }^{23}$ Victims' interests also have to be balanced with other sentencing priorities, such as deterrence, retribution, rehabilitation and public protection. That said, victims' input on the harm they have suffered could help to ensure retributive goals of proportional punishment, thereby improving the quality of justice. ${ }^{24}$ From a more victimological perspective proponents of victim inclusion in sentencing have been criticised for instrumentalising victims in retribution. ${ }^{25}$ This has been well documented in the United States with victims able to present their statement in person or through a video and to recommend a specific sentence. ${ }^{26}$ In contrast in the UK there has been a more measured use of VPS, where victims' experience of suffering is used to inform sentencing, rather than dictate it. This reflects that sentencing remains "public policy rather than private preference, ${ }^{27}$ but the harm of the victim is considered as part of the public interest. ${ }^{28}$ Nevertheless, victim statements in sentencing benefit the court in contextualising the personal harm suffered by the victim and reflecting its gravity in the sentence.

VPS are viewed as key in enabling victims to achieve expressive and communicative functions of participation by allowing them to inform the court of their harm and for it to be reflected through the sentence and judgment. ${ }^{29}$ Edwards suggests that victim participation can have an impact on proceedings and outcomes through four categories: decision-making; consultation; information; or expressive dimensions. ${ }^{30} \mathrm{UK}$ judges have been clear that

\footnotetext{
${ }^{22}$ R. Killean, Procedural Justice in International Criminal Courts: Assessing Civil Parties' Perceptions of Justice at the Extraordinary Chambers in the Courts of Cambodia, International Criminal Law Review 16 (1) (2016) 1-38, 16-18.

${ }^{23}$ I. Edwards, The evidential quality of victim personal statements and family impact statements, International Journal of Evidence \& Proof, 13(4) (2009), 293-320, 299.

${ }^{24}$ Erez, n.20.

${ }^{25}$ J. Doak, R. Henham, and B. Mitchell, Victims and the Sentencing Process: Developing Participatory Rights? Legal Studies 29(4) (2009) 651, 654.

${ }^{26} \mathrm{~J}$. Roberts, Listening to the Crime Victim: Evaluating Victim Input at Sentencing and Parole, Crime and Justice 38(1) (2009) 347-412.

${ }^{27}$ Ashworth, n.4, 505.

${ }^{28}$ Doak et al., n.25, 2009,657.

${ }^{29}$ Roberts and Erez,n 6, 225.

${ }^{30}$ I. Edwards, An Ambiguous Participation: The Crime Victim and Criminal Justice Decision-Making, British Journal of Criminology 44 (2004), 967-982.
} 
victims' opinions on sentencing are irrelevant, but their harm can inform the appropriate sentence. ${ }^{31}$ While this clearly rules out victim participation being about decision-making or consultation, it suggests that VPS is informative and expressive, yet its impact on sentencing can be indiscernible for all but legal practitioners. In turn, it dilutes procedural justice notions of process-control and perceptions of representation and accuracy of victims' expression of harm in sentencing. Essentially the VPS is another means for victims to testify as a witness on their harm as a consequence of the crime, a factual exercise to provide further evidence. This can have useful informative value for the court in determining aggravating factors for sentencing. The VPS can also has expressive benefits for victims by giving them public space to have their suffering expressed and 'heard' by the court, the defendant and wider public. Nonetheless, there remain tensions between victim expectations of procedural justice and the purpose of the criminal justice system in ensuring fair trial guarantees of accused persons during trial and punishment. In light of these debates, it is worth turning to consider the origin of VPS.

\section{The rise of Victim Personal Statements in criminal proceedings}

Victim Personal Statements (also know as Victim Impact Statements) were first used in common law courtrooms in California in $1976,{ }^{32}$ and followed in other US states soon after, New Zealand and Australia in 1987, and Canada in 1988. ${ }^{33}$ In England and Wales, Victim Personal Statements (VPS) were piloted in the late 1990s before being introduced nationwide in 2001 as part of the government's Victim Charter to enable victims to better inform the criminal justice system in how the crime affects them. Since then there has been an increasing jurifidication of victims role in sentencing with the English Court of Appeal Perkins and Others $v R,{ }^{34}$ finding that VPS are a 'right', a form of evidence to be heard in open court and can be cross-examined, but exclude victims' opinion on the sentence. This is further entrenched with EU Directive 2012/29, which requires all Member States to pass legislation that inter alia provides that victims with the 'right to be heard' in criminal proceedings, whether through oral or written statements. ${ }^{35}$

The Northern Irish experience of VPS has been somewhat different, being used by judges since the 1980s with only recent formalisation in the Victim Charter and the Justice Act (NI) 2015. Under the old system victim statements in NI were made through Victim Impact Statements or Victim Impact Reports, requested at the judges' discretion. The Victim

\footnotetext{
${ }^{31} R v$ Nunn [1996] 2 Cr App R (S) 136, 140.

${ }^{32}$ K. Kennard, The Victim's Veto: A Way to Increase Victim Impact on Criminal Case Dispositions, California Law Review 77(2) (1989) 417-453.

${ }^{33}$ J. Roberts, and M. Manikis, Victim Personal Statements A Review of Empirical Research, Report for the Commissioner for Victims and Witnesses in England and Wales (2011).

${ }^{34}$ [2013] EWCA Crim 323.

35 Article 10, EU Directive 2012/29.
} 
Impact Statements (VIS) were usually letters written by victims on how the crime impacted them. In contrast Victim Impact Reports (VIR) were prepared by psychiatrists or psychologists, to provide a 'specialist opinion on the traumatic impact of the crime on the victim and any consequent needs of the victim. ${ }^{36}$ In a VIR the victim's account is recorded, but they are not able to provide any further comment or voice on the contents of the report. VIS and VIR could be used in cases together providing a personal and professional account of the victim's suffering. However, recent Court of Appeal judgments on the evidential value of VIR has questioned the ongoing value of relying on VIR in sentencing. ${ }^{37}$

In 2015 the VPS was placed on a statutory footing through the Justice Act (NI) 2015 to improve public clarity and victims' understanding in how to make such statements, as well as to expand the VPS scope from cases of homicide, GBH and sexual violence to all crimes. ${ }^{38}$ This codified approach came from the then draft 2014 Victim Charter. The Victim Charter was intended to set standards on the services to be provided to victims and expectations of how victims should be treated in the criminal justice system. ${ }^{39}$ Section 33 in the Justice Act (NI) 2015 provides a broad ambit for victims to make statements, without reference to sentencing, but a subsequent section obligates that in sentencing 'the court must in determining the sentence in respect of the offence have regard to so much of any victim statement. ${ }^{40}$ Yet unlike other jurisdictions the VPS in NI remain in written form and are only used for sentencing, whereas in the rest of the UK they can be submitted for decisions on bail, probation or prosecution decisions. The shift to VPS was meant to reflect in part the focus on the personal impact of the crime on the victim after the incident, so as to minimise, if not negate, any need to refer to the crime itself and avoid the responsibility of the accused. ${ }^{41}$ Despite this reform, the ambit of VPS in NI means that it has no impact on improving the procedural justice aspects of victims' interests in criminal justice proceedings beyond sentencing.

\section{The Process of Giving a Victim Personal Statement}

Victims are informed that they can make a VPS though a leaflet provided by the Victims and Witnesses Care Unit in the Public Prosecution Service when the letter approving the decision to prosecute is made. A statement is usually made after a conviction or guilty plea, but before sentencing. This contrasts with the experience in England and Wales, where VPS are taken

\footnotetext{
${ }^{36}$ Department of Justice, Provision of Victim Impact Statements and Victim Impact Reports: A Department of Justice Consultation, (2011), para.10.

${ }^{37}$ L. Moffett, Victim impact reports in Northern Ireland: Victims' voices influencing sentencing? Criminal Law Review (2016), 478-484.

${ }^{38}$ DoJ official A, Interview 1, June 2015.

${ }^{39}$ S.28(2), Justice Act (NI) 2015.

${ }^{40}$ S.35(2), Justice Act (NI) 2015.

${ }^{41}$ DoJ official A, Interview 1, June 2015.
} 
after the crime following the witness statement as it was felt that this was done too early before the full effects of the crime had manifest themselves. ${ }^{42}$ In NI, there was consensus amongst respondents that taking the VPS after the trial or guilty plea was appropriate, as it allowed the victim to reflect on the impact of the crime and the trial.

For victims writing down and reflecting on their suffering through their statement could be cathartic. A number of intermediaries noted that victims making the statement provided a 'sense of relief that they have all this down on paper', ${ }^{43}$ allowing them to unburden themselves, ${ }^{44}$ or to 'vent their spleen' ${ }^{45}$ One police officer suggested that for some victims it is a 'way of working through their bereavements'. ${ }^{46}$ Another officer found with a woman whose son was murdered, that the VPS 'sort of cleansed her soul a wee bit in relation to it, because she's a lot of stuff she has needed to say and this gave her the output to say it' ${ }^{47}$ Others were more cynical with one police officer feeling that it may 'help people and it might be therapeutic to a degree, but I don't know if it would give people closure' ${ }^{48}$ In all, for some victims a VPS can be helpful by getting them to confront the pain and loss they have suffered, indicating some procedural justice aspects of representation and voice. Yet the statement is not enough in itself or the same for all victims.

The extent to which the VPS demonstrated more procedural justice aspects of accuracy of voice, according to respondents, depended on both the 'caring skill of the statement taker' and how articulate a victim is in enunciating the harm they have suffered. ${ }^{49}$ In terms of the statement taker, victims do not directly petition the court, but their statement is made through a range of intermediaries tasked with recording the VPS and passing it onto the prosecutor. Different actors document the VPS depending on the crime or victim. For cases involving homicide or GBH they are prepared with a police (PSNI) Family Liaison Officer (FLO), with other crimes written by Victim Support NI and the NSPCC Young Witness Service if the victim is a child. Victim Support NI would deal with the greatest volume of VPS (doubling from 94 to 210 in the first six months of 2014 and 2015), given the expansion to all crimes, with the NSPCC only addressing a handful of cases.

In taking the statement intermediaries said they were sensitive to victims' voice, allowing them to write it out by hand or dictate it with the intermediary then typing or writing it up. One FLO said it was a 'free text' and 'like taking an evidential statement, we can't influence

\footnotetext{
${ }^{42}$ M. Hall, Victims of Crime: Policy and Practice in Criminal Justice, (Wilan 2009), p180-181.

${ }^{43}$ Victim Support Worker A.

${ }^{44}$ Defence Counsel A.

${ }^{45}$ Police Officer D.

${ }^{46}$ Police Officer E.

${ }^{47}$ Police Officer D.

${ }^{48}$ Police Officer A, Interview 7, June 2015.

${ }^{49}$ Prosecutor A, Interview 3, June 2015.
} 
what goes in'. ${ }^{50}$ A senior police officer responsible for the FLOs, who also had personal experience in making a VPS for a family bereavement, outlined that 'generally speaking this is a verbatim statement recorded at someone's dictation essentially so what goes into it really isn't up to us; we influence what should go into it in terms of financial and psychological impact, but essentially it's down to the victim to actually give those words, and sometimes they are very powerful'. ${ }^{51}$ In terms of procedural justice, while intermediary involvement does not mean that victims' voices are shared with those that facilitate the VPS, it does reflect the restraints placed on victims' process-control and representation, which can distort the accuracy of their voice In terms of articulation a number of respondents noted how a wellworded or emotionally charged statement by a victim could more effectively convey the full impact of the crime on their life. This can be reflected not just in the quality, but also length of the VPS, with statements ranging from a few sentences to five or six pages. For instance in a case of theft, a prosecutor recalled how a woman had money stolen from her children's money box by her cleaner wrote a nine page VPS, 'it was very little money really that was taken out of her children's money boxes, but it was just the abuse of trust she felt very let down' ${ }^{52}$ This raises issues on consistency of statements and the ability of more expressive victims to sway judges to impose heavier sentences, than a more reticent or inerudite person. This was reflected by a judge who found that 'you never know what the VPS will say, some can be more powerful than others, more persuasive'. ${ }^{53}$

There can also be multiple VPS in a single case, which can have implications on the resources available for recording the statement and the impact on sentencing. In the $R v$ Connors murder case there were 10 VPS submitted to the court. ${ }^{54}$ In a case involving a death caused by a road traffic accident one FLO recalled 15 members of a family wanted to make VPS, but the officer agreed to do eight, as it takes on average two-three hours to do a single statement. Such cases impact on officers and other intermediaries' workload and other work commitments. The Justice Act (NI) 2015 now provides for a collective VPS for families to complete. ${ }^{55}$ While multiple VPS increase the workload of intermediaries in assisting victims to complete a VPS, it also raises difficulties for competing voice amongst victims and collectivising victims' voices. There is a perception amongst legal practitioners that multiple VPS in a single case can 'dilute the impact of those views' ${ }^{56}$ Although the VPS is meant to provide a picture of the personal harm suffered by victims because of the crime, it may be distorted by how their voices are presented through multiple prisms of different family

\footnotetext{
${ }^{50}$ Police Officer C, Interview 9, June 2015.

${ }^{51}$ Police Officer C.

${ }^{52}$ Prosecutor A.

${ }^{53}$ Judge C, Interview 21, September 2015.

${ }^{54}$ [2011] NICC 35 [11].

${ }^{55}$ Section 33(2).

${ }^{56}$ DoJ Official B, Interview 2, June 2015.
} 
members affected by a crime. Nonetheless, judges in cases like Connors where there are multiple victim statements, are able to discern the manifold suffering of family members and allow a pluralistic understanding of the victim and impact of the crime on their family.

\section{Framing the VPS}

Although the VPS can offer victims an outlet to express their suffering, it is still treated as a piece of evidence, subject to cross-examination and limited to the charges and facts before the court. Ensuring the victim's voice remains within these bounds necessarily requires some framing by those who help to prepare or submit VPS to the court. In the taking of a VPS, intermediaries assisting in the drafting of the statement will encourage the victim to make reference to the headings referred to in the Department of Justice guidance, such as physical and psychological harm, and any financial loss. These headings help to give the statement 'shape', ${ }^{57}$ and make it appear less of a 'rant'. ${ }^{58}$ Intermediaries often informed victims that inappropriate language or opinion on the appropriate sentence or punishment for the convicted person should be excluded or will be redacted. ${ }^{59}$

A prosecutor will include the VPS in her/his sentencing submission to the court after they have edited it. The prosecutor may read out the statement in part, whole or not at all at their discretion. This reflects the selective use and 'interpretation' of VPS 'are in the hands of the prosecutor presenting the case' ${ }^{60}$ Prosecutors can undermine the communicative function of VPS by taking away the uniqueness of a victim's story, emphasising different aspects, and representing victims' harm in generic terms may understate impact of the crime.${ }^{61}$ Once the prosecutor has edited the statement, it will be disclosed to the defence who will also have an opportunity to further redact it before the judge reads it. This instrumentalisation of VPS sees victims' statements being mediated by other actors in the criminal justice system for their own ends, undermining process-control and victims' perceptions of procedural justice in how accurately their harm is being represented. ${ }^{62}$

There are good reasons for redactions. Defence counsel found that they often edit the statement if it is not backed up by medical evidence. As one defence counsel remarked 'not all victims are objective, and not all victims are necessarily reliable'. ${ }^{63}$ They continued that:

'You do tend to find that a necessity for an awful lot of editing in those documents. It would be rare that you would get one that you didn't have to edit because it contains

\footnotetext{
${ }^{57}$ Police Officer C.

${ }^{58}$ Police Officer B, Interview 8, July 2015.

${ }^{59}$ Victim Support worker A, Interview 5, July 2015.

${ }^{60}$ Hall, n.42, 107.

${ }^{61}$ Roberts and Erez,n 6, 228.

${ }^{62}$ M. Manikis, Victim Impact Statements at Sentencing: Towards a Clearer Understanding of their Aims, University of Toronto Law Journal 65(2) (2015) 85-123, 101

${ }^{63}$ Defence Counsel A.
} 
a lot of fairly volatile and very emotional statements about what they think should happen to the defendant ... I've seen some very, very informative and very, very powerful and passionate victim impact statements, but again they have to be treated very carefully to make sure that they don't unduly prejudice the judge by including material which would interfere with the judges ability to fairly sentence a defendant. ${ }^{, 64}$

There is also a danger that victims may exaggerate or put unsubstantiated claims into their statement that would unfairly prejudice a defendant. ${ }^{65}$ As one defence counsel recalled with one victim statement of a mother in a murder case "she was saying ... he was unrecognisable, he was beaten to a pulp, which actually wasn't true that was a rumour that had been spread round the community'. ${ }^{66}$

A Victim Support NI worker recounted that in one case a victim claimed that as a result of the crime they developed fibromyalgia and the 'judge didn't believe that would have happened. He thought that was maybe an over inflation of what actually did happen and it actually went against the victim'. ${ }^{67}$ One prosecutor suggested that some victims can suffer from a 'bit of a claimitis' ${ }^{68}$ Despite noting the risk of exaggeration of victims' harm, there are perceived limits by defence counsel in challenging victims' harm through cross-examination, using instead redactions before the sentencing hearing. With senior counsel dealing with more serious offences, such as murder and sexual violence, one remarked that

'you are certainly always very, very careful not to be seen to be causing any more damage to the character or the truthfulness of the honesty of the victim its seen as kind of compounding the harm [through cross examination]... Rather than do that you just leave it, because the prospect of damage that you can cause to your client's claims for leniency and discount for the guilty plea. ${ }^{69}$

This lack of cross-examination by defence counsel to comply with sensitive practices of the court in the hope of a reduced sentence is apparent in other jurisdictions. Erez in discussing England and Wales found that there were similar 'strategic disincentives militating' against defence counsel cross-examining the victim impact statement. ${ }^{70}$ In the Republic of Ireland, McGrath also identified that cross-examination was unnecessary as the defence counsel can edit the statement before it is submitted to the court and had little impact on the sentence. ${ }^{71}$

\footnotetext{
${ }^{64}$ Defence counsel A, Interview 12, July 2015.

${ }^{65}$ Magistrate A, Interview 18, August 2015.

${ }^{66}$ Defence Counsel A.

${ }^{67}$ Victim Support Worker A.

${ }^{68}$ Prosecutor C, Interview 14, August 2015.

${ }^{69}$ Defence Counsel A.

${ }^{70}$ Erez n.20, 549; Ashworth n.4, 507; Sanders n.5. 454.

${ }^{71}$ Anthony McGrath, Is anybody listening, and why do they hear? The use of victim impact statements in Ireland, Dublin University Law Journal 30 (2006) 71-99, 6.
} 
Redacting or editing the victim's statement is what Edwards terms maintaining 'quality control' of a piece of evidence, rather than capturing victims' voices. ${ }^{72}$ Prosecutors can 'sanitize' the impact of the personal harm of the victim or represent their suffering in 'clinical' terms. ${ }^{73}$ Englebrecht and Chavez suggest that '[a]ny constraints placed on participation are likely to diminish the therapeutic value' of victims engaging with VPS. ${ }^{74}$ That said framing the VPS to just those crimes of which a defendant has been convicted, very much narrows the victim's experience of suffering. As such the framing of victims' voice, while to some extent necessary in maintaining the rights of the defendant, pays little heed to a victim's emotional experience and voice. . In light of procedural justice, such tight processcontrol of victims' voices and how it is represented could affect victims' perceptions of fairness and influence of their VPS on sentencing decisions. However as victims never see their statement again, the extent to which prosecutors and judges use it in sentencing hearings and decisions plays a more important role?

\section{Hurdles in Making a VPS}

The process of taking a VPS can discourage victims from making a statement. Here we discuss three main hurdles: cross-examination; intimate perpetrator crimes; and the legacy of the Troubles. These reflect the practical challenges in making VPS inclusive and a measure of procedural justice, due to the secondary victimisation they pose to some victims. With regards to the first of these, VPS are treated as evidence allowing defence counsel to cross-examine victims on the veracity and reliability of their statement. As one prosecutor stated crossexamining a victim on a VPS,

'would have dire consequences.... it's just horrific for a victim to go through the adversarial court system, absolutely horrific and to me nearly that's the problem, that's the root of it, the whole system, you can tinker all you like with victim impact statements, but you nothing is going to change the fact that you have to go into a witness box, you have to tell your story and then to the jury as strangers and then you have to be cross examined? I mean people will say afterwards their hearts sinks. ${ }^{, 75}$

As such, the fear of facing cross-examination, perhaps for the first time if the victim did not testify at the trial, could discourage them from making a VPS. ${ }^{76}$ Yet, as discussed, victim cross-examination is a risky defence strategy when trying to demonstrate the defendant's good behaviour, and therefore more of a perceived than practical risk.

Second, disclosure to the defence can silence some victims. Certain victims of intimate perpetrator crimes, such as domestic violence or child abuse, may be unwilling to make a VPS, given that the perpetrator could use the knowledge of the harm caused in future

\footnotetext{
${ }^{72}$ Edwards n.23, 319.

${ }^{73}$ Roberts and Erez n.6, 228.

${ }^{74}$ C. Englebrecht, and J. Chavez, Whose Statement Is It? An Examination of Victim Impact Statements Delivered in Court, Victims \& Offenders 9(4) (2014), 386-412, 387.

${ }^{75}$ Prosecutor A.

${ }^{76}$ Edwards, n.23, 300.
} 
attacks or as emotional abuse, such as being unable to sleep or bed wetting. ${ }^{77}$ As one intermediary suggested,

'if you are a victim of domestic violence do you really want this person who has power over you for so long to know the impact that they have had on you and how that they have totally affected your life? ${ }^{, 78}$

Once submitted, ownership of the victim's voice through the VPS is forfeited and can be used as much or as little by criminal justice actors and will be disclosed to the defendant. Although intermediaries will inform victims that anything they write in the VPS will be seen by the defence, it can have the effect of minimising or suppressing certain harm or circumstances of the victim, limiting their voice and experience. This corresponds to Erez and Rodger's view that VPS can silence some victims, as they 'are successful in maintaining the time-honoured tradition of excluding victims from criminal justice with a thin veneer of being part of it. ${ }^{79}$

Victims can refuse to make a VPS. In $R v$ Chen and others, three victims of human trafficking for the purposes of sexual exploitation, testified during the trial, but refused to make a VPS. ${ }^{80}$ A magistrate suggested that where a victim refuses to make a statement, there is an informal practice of the judge querying the prosecution as to why and whether they have met with the victim. ${ }^{81}$ In the both these cases there was other evidence on the harm suffered by the victims. Refusing to make a VPS reflects a victim's agency, but it signifies that sensitivity is needed around disclosure to protect more vulnerable victims from future victimisation by the perpetrator i.e. child abuse or domestic violence. Not all victims are the same. There should be fresh thinking on how to allow vulnerable victims to submit a VPS to inform the court of their experience, without fear of further violence or all the particulars being revealed to the defendant, such as pre-recorded video statements. A fine balance needs to be struck between ensuring the veracity of the harm caused to the victim, sufficient protection of their privacy and ability to inform the court of their suffering. Otherwise individuals who have suffered from serious harm could have their voice and personal experience silenced by the system itself in sentencing proceedings. This undermines notions of procedural justice and respect for the personal voice of the victim as a participant. For victims as participants perceptions of procedural justice are not just about voicing their views, but also about being heard and their interests being considered by judges in sentencing.

A final hurdle is continuing distrust of the police and the criminal justice system by some people in Northern Ireland, as a consequence of the Troubles that still casts a long

\footnotetext{
${ }^{77}$ NSPCC Worker A.

${ }^{78}$ Victim Support Worker A.

${ }^{79}$ Edna Erez and Linda Rodgers, Victim Impact Statements and Sentencing Outcomes and Processes: The Perspectives of Legal Professionals, British Journal of Criminology 39(2) (1999) 216-239, 235.

${ }^{80}$ [2012] NICC 26. See also $R v$ Balmer and another [2015] NICA 40.

${ }^{81}$ Magistrate A, Interview 18.
} 
shadow over some communities' engagement with it, due to findings of collusion between the former police force, the Royal Ulster Constabulary, loyalist paramilitaries, as well as use of internment and enhanced interrogation. ${ }^{82}$ As one FLO recalled 'my very first deployment was a murder in North Belfast and the first words out of the fathers mouth were Danny McCaughan didn't get justice, such and such didn't get justice and I'm not f'ing expecting justice ${ }^{83}$ Another reported that they had the door closed in their face three times by the family of a murdered victim before they were able to put their foot in the door and speak to them. ${ }^{84}$ Other FLOs discussed how they had to engage the victim through a solicitor or community representative, as the victims did not want to have any contact with the police. ${ }^{85}$ One FLO explained that in her experience a family did not trust her as a member of the police even if she was trying to inform them of the investigation and assist in filling out the VPS,

'it's very difficult to build any kind of relationship with them and when it comes to making victim impact statements ... they would want to say a lot about police mishandling of the investigation ... I would say that's had more of an effect on them than the murder themselves, that's what is really biting them. ${ }^{, 86}$

Although many of these engagements with families are in relation to contemporary murders, the perceptions of the police of the past within certain communities creates a barrier for victims being able to inform the court of their suffering, or at least inhibit its effectiveness. This reflects wider structural issues with the criminal justice system and procedural justice in post-conflict societies.

\section{Being heard: The impact of Victim Personal Statements on sentencing}

The VPS as only a written representation of a victim's 'voice' has the effect of flattening the emotional expression, tone and emphasis of their suffering. More functionally, as one judge indicated, the VPS 'can be kept under control if it is kept in writing. It is structured and less likely to give concerns ${ }^{87}$ The VPS is informative in clarifying the judge's decision on the sentence through 'material to the question of harm', ${ }^{88}$ a fact-finding exercise removed from the uncertainties of emotion. But what impact does it have, if any, on sentencing? For victims the VPS can provide a communicate outlet to the court on the particulars and gravity of the

\footnotetext{
${ }^{82}$ See Kieran McEvoy, What Did the Lawyers Do During the 'War'? Neutrality, Conflict and the Culture of Quietism, The Modern Law Review 74(3) (2011) 350-384; and John Topping, Policing in Transition, in A. McAlinden and C. Dwyer (eds.), Criminal Justice in Transition: The Northern Ireland Context, Hart (2015), 71-86.

${ }^{83}$ Police Officer D, Interview 10, July 2015.

${ }^{84}$ Police Officer E, Interview 11, July 2015.

${ }^{85}$ Police Officers D and E.

${ }^{86}$ Police Officer B.

${ }^{87}$ Judge C.

${ }^{88}$ Judge A, Interview 13, August 2015.
} 
harm they have suffered as a result of the crime. As one Victim Support worker found the VPS,

'gives the victim a wee bit of power back over the whole process, because ... The victim seems like the unimportant person, it's all about the offender. The victim can feel very much forgotten about ... at least through this statement that they are getting some kind of a say in the process and someone in authority is listening to how this has impacted on them. ${ }^{89}$

The VPS serves a vital role in capturing the victim's voice, even if other actors redact it or the judge does not refer to the statement, at least it becomes part of the court record. As one NSPCC support worker found,

'it's really important to have the child's voice central to the proceedings ... You've got a whole system running and it's not designed for the victim or the witness and so this is another way to get the child's voice in there'. ${ }^{90}$

The VPS can also send moral messages about the defendant's responsibility in the crime as a way of 'shaming' the defendant by laying bare the harmful consequences the crime has had on the victim and their next of kin. ${ }^{91}$ One prosecutor found that in a case involving a heavily pregnant woman who lost her baby in a car crash close to term, the VPS was helpful, that even though she wanted the driver of the other car prosecuted,

'she had stated she forgave him and she was able to move on and she had gone onto have another child, but she really didn't want him to be heavily sentenced. In cases like that where they want a conviction, but not really not everything to be thrown at him, it helps the court to understand all the emotions and stuff involved. ${ }^{, 92}$

This is not to suggest that VPS can always provide a sort of restorative justice forum in criminal sentencing, but it can help to return some of the victim's agency and identity undermined by the defendant during the crime by confronting them and the court with the harmful effects. ${ }^{93}$

The VPS can have therapeutic benefits by the victim's harm being publicly acknowledged. This reflects both the practice of emoting, i.e. public sharing their emotions, and procedural justice in how their voices are accurately respected and considered by the

\footnotetext{
${ }^{89}$ Victim Support worker A.

${ }^{90}$ NSPCC Worker A, Interview 6, July 2015.

${ }^{91}$ Police Officer B.

${ }^{92}$ Prosecutor A.

${ }^{93}$ J. Doak, and L. Taylor, Hearing the voices of victims and offenders: the role of emotions in criminal sentencing, Northern Ireland Legal Quarterly, 64(1) (2013) 25-46.
} 
criminal justice system. ${ }^{94}$ Lens et al suggest that there are no direct therapeutic effects from making a VPS, but feelings of anxiety can decrease where they feel satisfied by how they feel they were respected and treated. ${ }^{95}$ The VPS can offer a way to acknowledge the victims' suffering through their inclusion in the sentencing process. Judges reading out the VPS in their sentencing remarks can publicly acknowledge the victim's experience, making their suffering official and giving a valued place for their voice. ${ }^{96}$ Acknowledgement can help to give the victim a human face, rather than the anonymous outsider, as one prosecutor noted this acknowledgement by judges - "really helps that this person was a person, rather than just simply a statistic". ${ }^{97}$ This recognition of the victim can evince procedural justice aspects of representation and accuracy of sentencing decisions in accounting for the harm victims suffered.

Erez found that judges citing victims' statements made them 'feel gratified when their sense of harm is validated in judges' remarks'. ${ }^{98}$ This serves an almost communicative function that the victim's voice is heard, listened to by the judge and echoed in their sentencing remarks. One defence counsel remarked that

'victims and their families do probably at least feel that they've been heard and a judge refers to the [VPS]... I suspect that probably gives the families at least the sense they have been listened to and that their views have been taken into consideration. I suppose maybe that's part and parcel of this whole idea that justice needs to be seen to be done. ${ }^{99}$

However, analysing sentencing judgments and remarks by judges in NI over the past 20 years found very few instances where judges quoted the victim's statement, though judges would often note that they have received it and found it helpful. Some prosecution counsel and judges noted that referencing or quoting the VPS were often kept to a minimum to avoid victims' statements being subject to an appeal. Yet this clearly diminishes the procedural justice aspects of consistency, representation and accuracy if victims are unable to discern their input. That said the potential of acknowledgement represents reciprocal benefits for some, but not all victims. Nevertheless, the lack of acknowledgement in the judge's remarks can inhibit victims' and intermediaries' perceptions of impact and value of the VPS in sentencing.

\footnotetext{
94 Ibid.

${ }^{95}$ K. Lens, A. Pemberton, K. Brans, J. Wageningen, S. Bogaerts and E. Lahlah, Delivering a Victim Impact Statement: Emotionally effective or counterproductive? European Journal of Criminology, 12(1) (2015) 17-34, 30-31.

${ }^{96}$ Doak et al., n. 25668.

${ }^{97}$ Prosecutor A,

${ }^{98}$ Erez n.20, 553.

${ }^{99}$ Defence Counsel A.
} 
Espousing the therapeutic benefits of VPS for victims is seen as a 'soft' role for them, where they are denied participatory rights and instead given more of a token gesture to keep them satisfied and engaged. This can reflect Ashworth's arguments in favour of service rights over procedural ones on victim participation in improving respect for victims rather than influencing decision-making. ${ }^{100}$ As one senior police officer said: 'I don't think that judges pay much attention to the victim impact statement in a murder investigation. It's more of a cathartic tool for the family to be able to express what a devastating effect the murder of the loss of a loved one has had ${ }^{101}$ Some view VPS as having little impact on the sentence, and is just a conciliation prize for victims. One senior counsel said 'although undoubtedly it probably does have some impact upon sentence, the value really is in the degree to which it helps victims and makes them feel that they are being heard and taken into consideration'. ${ }^{102}$

These sentiments reflect the experience in other jurisdictions where the therapeutic label has been attached to victim statements in sentencing, but in practice they are blunt therapy tools. ${ }^{103}$ Doak, Henham and Mitchell note the 'danger in attaching the 'therapeutic' label to criminal justice initiatives, which, while promoting 'participation on paper, actually do very little in practice to encourage a form of participation that is both meaningful and effective in terms of catharsis. ${ }^{104}$ More cynically one defence lawyer suggested that VPS helps to neutralise public perceptions of weak sentences and apathy of judges to victim suffering; whereas without a VPS the newspapers would jump on a story where the victim was outraged that their suffering was not taken into account. ${ }^{105}$ It may be the case that VPS are a way of managing and mollifying victims. Yet as Tyler suggests, only allowing victims to voice their interests and not taking them into account may have short-term valueexpressive benefits (such as emoting) but in the long term the failure to shape sentencing will cause them frustration, disengagement and loss of satisfaction with the criminal justice system. ${ }^{106}$ This feeds back to Thibaut and Walker's research on procedural justice that ensuring satisfaction is not enough if it is not being seen at least to be considered in decision making. At best, the VPS may not be therapeutic for all victims, but it can contribute to victims having a better understanding of the sentencing process and what was involved in it.

\section{Measured expectations and measured justice}

Writing a VPS can encourage victims to have measured expectations of the likely outcome of sentencing and what the criminal justice system can and cannot do. As a Victim Support worker found, victims can 'sometimes ... have a very inflated opinion of what is going to

\footnotetext{
${ }^{100}$ Ashworth, n.3, 509.

${ }^{101}$ Police Officer B.

102 Defence Counsel A.

${ }^{103}$ Lens et al (2015), n. 96, 30

${ }^{104}$ Doak, Henham and Mitchel, n. 25, 668.

${ }^{105}$ Defence Counsel B.

106 Tyler n. 13 .
} 
happen on the back of this statement that it is going to work miracles', but through the VPS and engagement with an intermediary can help to inform those expectations. ${ }^{107}$ Similarly, one FLO remarked in a case of a mother giving an impact statement against the man convicted of manslaughter as a co-accused rather than a direct perpetrator over the death of her son, the VPS helped her to

'put on record the best of her thoughts. Ultimately she knows the guy that murdered her son isn't going to get prosecuted for murder and she's really not happy. But you're never going to be happy. I know if it was my kids, seeing them hanging from a lamppost would be enough, but you got to be big enough to understand justice works in certain ways. We are not in the Wild West unfortunately or fortunately! 108

Accordingly while the retributive function of VPS in increasing a sentence may be limited, the VPS can at least better inform victims of sentencing and their role in it. This corresponds to literature on procedural justice and role of information in providing a 'cushioning effect' where outcomes were not expected. ${ }^{109}$ However, Killean suggests that such a cushioning effect in sentencing outcomes will likely be ineffective in serious crimes were there is an acquittal or an overly lenient sentence. ${ }^{110}$ In the procedural justice literature such a cushioning effect in creating measured expectations for participants, where they have no direct impact on decision making, will only exist where they are able to participate and feel that they have voiced their interests. ${ }^{111}$ To an extent the expansion of VPS to all crimes in Northern Ireland may be effective in having a cushioning effect and procedural justice benefits for minor crimes, but where the statement is perceived as having no impact on sentencing in serious crimes it may be detrimental to achieving the goals of the Victim Charter.

\section{Impact on Decision Making}

Procedural justice for victims is also concerned with their views being considered and can be seen to have some sort of impact on a judges' decision making in sentencing. ${ }^{112}$ Judges and prosecutors shared the perception that victim statements do have an impact on sentencing. As one magistrate said 'we have always regarded it [the VPS] as very important, because the

\footnotetext{
${ }^{107}$ Victim Support Worker A.

108 Police Officer D.

${ }^{109}$ See Killean, n. 22, 26.

${ }^{110}$ Ibid. 26-27.

${ }^{111}$ L. Walker, E. Allan Lind and J. Thibaut, The Relation between Procedural and Distributive Justice, 65(8) Virginia Law Review (1979) 1401-1420, 1418.

${ }^{112}$ Wemmers, n. 17.
} 
impact on the victim has always been an important feature in sentencing as a potential aggravating factor'. ${ }^{113}$

VPS intermediaries viewed the statement as having more of a therapeutic role, as the veil of judicial discretion makes it very difficult to discern what impact victims' statements have on sentencing. This sits in stark contrast to the perceptions and understandings of sentencing by legal practitioners. This dissonance may reflect the distinction between nonlawyers and the legal profession, and the legalese shroud around sentencing practices. As one NSPCC worker argued,

'the legal world is a world all of its own ... It has its own etiquette, its own rules, and when you go into it you're very conscious that you're in this legal arena.' 114

Judges and prosecutors do refer to the VPS for consideration as an aggravating factor in sentencing. ${ }^{115}$ The VPS serves a valuable function in informing the court on the extent of the harm caused by the crime. ${ }^{116}$ The VPS serves informational and retributive roles for the court. However, the use of the VPS is more nuanced in terms of (1) the type of victim and crime, and (2) how judges and prosecutors include the statement in their judgments and remarks. This goes beyond retribution, by the court communicating expressive moral messages that publicly acknowledge the victims' experience. With the first of these, the weight of the VPS for sentencing depends on the kind of victim and crime. There are a range of standards on sentencing for different crimes in NI depending on the sentencing practice statement. For instance on murder/manslaughter ${ }^{117}$ and child abuse ${ }^{118}$ that take into account the victim's harm as an aggravating factor.

Victim vulnerability is an important aggravating factor for sentencing. Elderly victims, ${ }^{119}$ and children who have suffered sexual violence or abuse, ${ }^{120}$ are considered to suffer increased harm, which is then reflected in the sentence. It also raises the profile of the individual victim's harm in 'less' serious offences, such as theft. As one judge commented, the 'expansion [of the VPS] into all offences is perhaps overkill in every case. On the other hand in cases of burglary or an assault in the street it can be useful, as you can lose sight of the

\footnotetext{
${ }^{113}$ Magistrate A, with similar comments by Judges A and C. This position is now codified as an obligation under s.35(2), Justice Act (NI) 2015.

${ }^{114}$ NSPCC worker B, Interview 19, October 2015.

${ }^{115} R v$ Holmes and $R v$ Kerr [2009] NICC 79 at [25] and [45]).

${ }^{116} R v$ Chen and others [2012] NICC 26 at [49].

${ }^{117} R v$ McCandless [2004] NICA 1.

${ }^{118} R v M L[2013]$ NICA 7.

${ }^{119} R v A B$ [2012] NICC 27 at [10]; and $R v$ Cambridge [2015] NICA 4.

${ }^{120} R v$ Curran [2013] NICA 1 , at [13].
} 
harm to the victim, especially a woman or elderly person living on their own or in cases of violence impact can still be profound'. ${ }^{121}$

There is a danger that with increased use of the VPS and perceived vulnerability of certain victims, their harm becomes normalised in sentencing decisions, disregarding the individual's experience by assuming their harm. Commentators in other jurisdictions have found that the impact of the crime and details could be anticipated and expected by legal practitioners based on the charge. ${ }^{122}$ As such, 'the victim of a crime ceases to be an individual, with idiosyncratic responses to his/her experience, but is reduced to the victim of the specific crime category with it concomitant injuries. ${ }^{123}$ This corresponds to similar experiences in the rest of the UK where the common use of the VPS leads to production of 'mundane predictable information' in the majority of cases with 'nothing unexpected, it inevitably makes no difference'. ${ }^{124}$ The VPS as a piece of evidence helps to confirm these assumptions.

The VPS can lead to duplication of material already before the court, such as medical reports, as according to one magistrate 'we are very aware of potential impact that these crimes do have on victims ... but we do not need victims to tell us we know, we know. ${ }^{125}$ Similarly a criminal court judge said: 'A victim's harm does not come as a surprise. The danger with judges hearing a case after case without a victim personal statement is that they may lose sight of the victim behind the crime. It helps to put a proper, personal context., ${ }^{126}$ Nonetheless one senior prosecutor noted that,

'the offences in themselves are almost so serious that it goes hand in hand that such is the nature of the offence, abuse of a child or something like that is likely to leave a lasting permanent deficit. I've personally never found any judge rushing themselves to find the harm more than it is. I found the judges to be very careful to ensure that they are only relying on what evidence they can properly rely upon. So it's not a knee-jerk reaction, far from it. ${ }^{127}$

The value-expressive dimension of how the VPS is used by prosecutors and judges is considered valuable. As one judge elegantly found 'it is helpful to hear the victim's voice, it helps to breathe life into the facts'. ${ }^{128}$ The VPS helps to humanise the victim, that they were 'much loved' 'a man dedicated to his family' and 'a young mother who had everything that

\footnotetext{
121 Judge C.

${ }^{122}$ Ashworth, n4, 506; Erez and Rodgers n.80, 220.

${ }^{123}$ Erez and Rodgers, ibid. 224.

${ }^{124}$ Sanders, n.5, 454.

${ }^{125}$ Magistrate A.

${ }^{126}$ Judge C.

${ }^{127}$ Prosecutor E, Interview 17, August 2015.

${ }^{128}$ Judge C.
} 
life could offer to look forward to', but also the profound and senseless loss of this human being. ${ }^{129}$ As one prosecutor said, the VPS,

'benefits the court in the because they have a fuller picture of the effect of the loss on the survivors, because very often you are just the victim, your role is almost to satisfy the criminal justice system - your "V". All of a sudden when you have those victim impact statements the court is reminded again that you were a person, and you were valued as a person. I think that's personal to me and obviously it has an effect as well on court ... for victim impact you've lost something very special here, this has had a devastating effect on your life and that's very important. ${ }^{130}$

As such, the VPS gives a more visceral and emotion connection to the personal suffering of an individual or family that moves beyond the banal legalese of court proceedings and a crime 'statistic'. Some judges also echo the VPS, such as in Re Boyle which involved a defendant murdering his flatmate, the judge in his sentencing remarks read from the VPS 'Our hurt is our human feelings, we miss him deeply, not being able to hear his voice or his laughter, never to see his smiling face, or embrace him. ${ }^{131}$ Accordingly VPS exhibits procedural justice factors of participants being best placed to represent their own interests to ensure accuracy in decision-making.

Judges can also empathise with victims' suffering and human loss, such as in $R v$ Healy where the judge commented that he 'recognises the terrible loss that this family has suffered', ${ }^{132}$ and in $R v$ Stephen Lee Wright and Russell Hector Hunter where the judge quotes the VIS as 'graphic evidence of the effects of the killing' of a sibling, taking into 'account on that basis as showing the damaging and distressing effects of this crime on his surviving close family'. ${ }^{133}$ However such remarks are not a verbatim reading of the VPS, but can be a summing up in a couple of sentences of the statements. ${ }^{134}$ In addition, judges have recognised the ongoing suffering victims face as a result of the crime (in particular sexual offences against children). ${ }^{135}$ Importantly, judges can offer affirmative statements to victims, acknowledging that despite the harm from the crime they are not broken, commending their robustness for those who have went on to study at university or progressed in their career. ${ }^{136}$

A few intermediaries noted the excellent practice of some judges in sensitively quoting the victim, placing their harm in the context of the crime and taking the time to read and reflect over the VPS. This acknowledgement can help to communicate to victims the

\footnotetext{
${ }^{129} R v$ McLaughlin [2013] NICA 55, $R$ v Coleraine Borough Council [2013] NICC 17, $R v$ Wright and others [2013] NICC 18.

${ }^{130}$ Prosecutor B, Interview 3, June 2015.

${ }^{131}$ [2004] NICC 13 at [16]-[17].

132 [2013] NICty 7.

${ }^{133}$ [2007] NICC 33 at [8].

${ }^{134} R v$ Black [2011] NICC 40 at [9].

${ }^{135} R v R D$ [2013] NICA at [12]; $R$ v Curran [2013] NICA 1 at [12].

${ }^{136} R v M L$ [2013] NICA 27 at [4]; $R v R D$ [2013] NICA at [10].
} 
value their input has in the decision making process that is instrumental in decision-control, rather than value-expressive. However, there was a consistent opinion amongst intermediaries that judges were very much detached from the personal suffering of the victim - 'at arm's length' ${ }^{137}$ and 'quite untouchable'. ${ }^{138}$ While recognising that judges have sentencing guidelines to work within 'some of the judges see themselves as totally detached from life nearly, they don't seem to live in the same world we all live in'. ${ }^{139}$ There is a need for judges to have some detachment and objectivity, which is difficult for intermediaries who are confronted with the human consequences of the crimes. As the FLO continued,

'there's another fatal this morning. You can be sitting here every day bawling your eyes out, you can't, there has to be a certain amount of detachment. I understand that the magistrates and judges too, but you have to recognise that this has been a huge impact on that whole family and that never ever goes away. ${ }^{140}$

Nonetheless, the detachment of judges and lack of consistent practice in engaging with the VPS in sentencing remarks reinforces the perceived futility of intermediaries working on victim statements.

Reference to or comment on the VPS is often rare and depends on the judge, undermining procedural justice concerns for consistency in decision-making and consideration of victims' input. Some of these remarks can be quite dispassionate and terse, such as in $R v$ Stockman where the judge stated that the two VIS 'speak of their sadness at the death of' in the manslaughter of a family member; ${ }^{141}$ whereas others can be quite detailed on the impact on different members of the family and family business in cases of murder $(R v$ Browne ${ }^{142}$ and $R v$ Stewart ${ }^{143}$ and $R v$ Carson). ${ }^{144}$ Indeed some judges will quote the VPS at length on the effect of the crime on the victim or family. ${ }^{145}$ This inconsistent practice reflects the discretion judges enjoy, but also perhaps their caution to explicitly state their reliance on the VPS for fear of 'downriver consequences', that is, being subject to an appeal. ${ }^{146}$ As one senior counsel remarked,

'you do tend to see judges reflecting on the contents of victim impact statements that undoubtedly it has an emotional effect upon them. Judges are maybe might find themselves somewhat torn between reflecting on the impact that an offence has had

\footnotetext{
${ }^{137}$ Police Officer C.

${ }^{138}$ Victim Support Worker A.

${ }^{139}$ Police Officer B.

${ }^{140}$ Police Officer E.

${ }^{141}$ [2011] NICC 36 at [9].

142 [2008] NILST 11 at [18-22].

143 [2004] NICC 23 at [27-29].

${ }^{144}$ [2004] NICC 5 at [17-19].

${ }^{145} R v$ Valliday [2010] NICC 14 at [8] and $R v$ Kerr [2004] NILST 13.

${ }^{146}$ Defence Counsel B.
} 
upon the family, but not allowing that to affect them in such to such an extent that it actually interferes with the proper dispensing of sentence in the case'. ${ }^{147}$

One senior judge took a more objective view that medical evidence will support a VPS and that these statements 'assist us in identifying accurately the harm' and 'appropriate' sentence, but that there is 'no particular impact' of the VPS which is taken into account when weighing harm and culpability with the sentencing brackets. ${ }^{148}$

Another FLO found VPS too emotional and judges too constrained by legal rules, sticking instead to legal certainty in their sentencing guidelines:

'generally I don't think that [the VPS] has any impact because he's looking at rules of law he is looking at all the background so he's not thinking well I'll add more time on because they are really upset, because who isn't going to be absolutely distraught family members been murdered. ${ }^{149}$

The lack of clarity around sentencing practices also taps into frustration with perceptions of light sentences and lower tariffs for murder in NI than in the rest of UK. This could reflect the association with intermediaries and victims that VPS is a tool meant to support the retribution function of sentencing in achieving more proportionate sentences. As one FLO said:

'It's actually the point in the investigation that I dread the most is the sentencing, cos I know that they are always going to be disappointed unless like flip it was a Masserene kind of incident [referring to the shooting of two soldiers by dissident Republicans in 2009] where they would actually get them some regular years. The guy who I was FLO for his family, he was a peeler and his father murdered his mum. He stalked her, stabbed her and beaten her round the head with a meat mincer. He got like fourteen years and I was sitting and her sister was in court next to me holding my hand like shaking the whole way through. She heard the sentence she was like what, what that's absurd. It's heart breaking watching that. ${ }^{, 150}$

That said a distinction can be drawn between cases of Troubles related murders and other serious offences, where judges more readily engage with the VPS, despite the likely short sentences that will result. As part of the Good Friday Agreement and under the Sentences (NI) Act 1998 those convicted for scheduled offences committed during the Troubles can only be imprisoned for two years before getting early release. As one FLO (Police Officer B) recalled 'it is a bit soul destroying and he'll get some pathetic [sentence]'. In another case the FLO discussed how family members were disillusioned with the criminal justice system, as one brother of a murder victim murdered by Loyalists in the 1990s told him 'I don't even

\footnotetext{
${ }^{147}$ Defence Counsel A.

148 Judge A.

${ }^{149}$ Police Officer B.

${ }^{150}$ Police Officer B.
} 
know why yous even bother, my brother wouldn't have wanted this. What's the point he'll get a couple of years. ${ }^{151}$

Despite the punitive futility of the VPS impact on the sentence for historic Troubles convictions, the role of a sentencing judgment in acknowledging victims' suffering becomes more central. Acknowledgement is the way in which to publicly recognise the human dignity and value of the victim, while bringing to light the full impact of the crime on them. This is apparent in the $R v$ Rodgers ${ }^{152}$ case involving the murder of a Catholic teenager by a Loyalist gunman in 1973. After being convicted 40 years later when new evidence emerged the sentencing judge having read the VPS stated:

'I have had the opportunity to consider the moving and detailed account of the effect Eileen's murder has had on her family from her sister Linda Marsden. It describes a young girl so full of life without a bigoted bone in her body with so much to look forward to, marriage, a family, a career, who was gunned down in her prime. The murder has left a bitter and lasting legacy for those who remained behind. Her father visited her grave at least on a daily basis unable to cope with the loss of his beloved daughter withdrawing into himself until he died 2 years ago. His wife had to shoulder the burden of bringing up Eileen's siblings. On 30 September 1973 the lives of all the members of the Doherty family changed utterly. They were never to be the same again. Eileen's father died, denied the satisfaction of seeing one of her murderer arrested, put on trial and convicted. ${ }^{153}$

As one judge noted in a historic murder during the Troubles he found that a VPS prepared by a boyfriend of the victim as a 'very moving' statement, which 'brought the crime to life, even to describe it as historic, nothing historic about it for the family and boyfriend as a daily suffering' and 'VPS are very helpful' ${ }^{154}$ Accordingly while the retributive function of VPS in increasing a sentence may be limited, the VPS and judges communication with victims through their sentencing remarks can offer valuable acknowledgement and a sense of procedural justice for victims.

For ordinary crime not related to the Troubles, the VPS impact on sentencing could also be limited to prevent a "new and unpredictable variable into the penalty equation and would jeopardise core principles such as just-deserts, proportionality, certainty and objectivity'. ${ }^{155}$ While there are good reasons for judicial discretion in sentencing, if VPS are to reach their goals of ensuring victims are heard and engendering a sense of procedural justice for them, they need to be more carefully crafted to acknowledge victims' input and judges must clearly state how their statement on harm is balanced with the defendant's

\footnotetext{
${ }^{151}$ Police Officer B.

${ }^{152}$ [2013] NICC 5

${ }^{153}$ Similar remarks in $R v$ McGeough [2011] NICC 16 [24]-[26].

154 Judge C.

${ }^{155}$ Doak, Henham and Mitchell, n. 25, 655.
} 
culpability. This is also important in informing perceptions and engagement by intermediaries in facilitating VPS.

\section{Conclusion}

The VPS allows victims' voices to be captured, but it does not mean they will be heard by the criminal justice system. This study in Northern Ireland reveals two main findings. First, victims make VPS not purely out of retribution, but also to seek official acknowledgement of their harm by a judge. In this way the VPS operates as a space for victims to feel their voice is heard. Second, hearing victims is muffled by the opaqueness of sentencing practices, whereby redactions limit the magnitude of victims' voices and the lack of sentencing remarks by judges on the role of the VPS in determining the sentence.

Despite increased top-down juridification from EU and the courts in cases like $R v$ Perkins, acknowledging victims' voices in VPS remains discretionary. Reform should be aimed at the process of taking a VPS and how it is used by judges to improve procedural justice for victims in terms of process and their interests being considered in sentencing.. First in taking the VPS, the statement could be video-recorded to capture the victims' voice and emotion that they may not be able to articulate on paper. Moreover, there should be greater opportunity to give victims the choice to read their statement out to the court, given that this will be after the judge has made their decision on the length of sentence. In the Republic of Ireland McGrath found that the victim reading out their statement in court after sentencing made it 'part of the offender's sentence and not a factor in determining it'. ${ }^{156}$ This can ensure better representation practices that the victim is a participant and greater process-control to state their case. Second, to better acknowledge victims' voice, judges should establish a protocol to quote the VPS in the sentencing judgment and victims should receive a copy of these sentencing remarks. This would help to propagate some sense of respect and procedural justice for victims. This practice has already been adopted by some judges (e.g. $R v$ Stephen Lee Wright and Russell Hector Hunter ${ }^{157}$ However, the VPS form should allow the victim to highlight areas they do not want the prosecutor or judge to read out in court, in order to protect their privacy and dignity. This reflects that the VPS operates as not just informing the court of the victim's harm, but a space for victims to confront the harm they have suffered.

Beyond these suggestions there was little appetite amongst intermediaries and legal practitioners to allow victims to have a bigger say in sentencing, i.e. give their opinion on the length of punishment or through a legal representative. Legal practitioners were very much wary of such an approach that would be more 'mob' justice ${ }^{158}$ or in contrast to the US's 'politicised justice system'; instead there was concern that in NI a clear separation of powers

\footnotetext{
${ }^{156}$ n.72, p12.

${ }^{157}$ [2007] NICC 33 at [8]).

${ }^{158}$ Defence Counsel A
} 
needs to be maintained. ${ }^{159}$ This reflects research in other contexts where allowing a victim to state the appropriate sentence was unsuitable, as they have no legal background or might simply be 'seeking revenge'. ${ }^{160}$ That said one barrister suggested that even if VPS were improved more fundamental reform is required to balance the criminal justice system for victims 'defendant's are rarely made to make good any loss or make up for the harm caused to victims and I think that implies the scant level of regard paid to victims, despite victim policies and charters that are enunciated by the criminal justice system through various organisations'. ${ }^{161}$ Procedural justice concerns of improving victim satisfaction cannot be satisfied by only allowing victims to voice their views, but such interests need to be considered. As such, procedural concerns of ensuring fairness and respect to victims cannot be detached from their role in informing outcomes, albeit in a measured way. Otherwise past problems of victims' interests being marginalised in the criminal justice system will only have the effect of creating a veneer of satisfaction and create long-term frustration and disengagement by victims, but also intermediaries involved in sustaining the work of the criminal justice system.

If we are serious about hearing victims' voices, then judges should accommodate victims' statements in their sentencing remarks. This sensitive personal outpouring should be carefully handled by courts, given its emotional and intimate value to the victim. Failing to acknowledge their voice and the role it plays in sentencing will leave victims and intermediaries feeling that the process was just perfunctory, as the experience in Northern Ireland suggests. Nevertheless, while the VPS may not be therapeutic for all victims, it can be an important procedural justice mechanism for judges to acknowledge the personal experience of victims and to offer them a place in proceedings that respects and appreciates their input in the decision making process. A better balance can be struck in Northern Ireland in hearing victims' voices in sentencing by allowing victims to read their VPS out in court and for judges to acknowledge or quote the statement in their sentencing remarks. Although victims do bring some amount of chaos to criminal proceedings, the VPS offers a structured means for victims to be participants. However, judges have an obligation to communicate to victims through their remarks that their voices are heard to engender a better sense of procedural justice.

\footnotetext{
${ }^{159}$ DoJ Official A.

${ }^{160}$ Annette van der Merwe and Ann Skelton, Victims' Mitigating Views in Sentencing Decisions: A Comparative Analysis, Oxford Journal of Legal Studies, 35(2) (2015), 355-372, 357.

${ }^{161}$ Defence Counsel C, Interview 23, October 2015.
} 
